\title{
Beyond categorization: New directions for theory development about entrepreneurial internationalization
}

\author{
A Rebecca Reuber ${ }^{1}$, \\ Pavlos Dimitratos ${ }^{2}$ and \\ Olli Kuivalainen ${ }^{3,4}$
}

\footnotetext{
${ }^{1}$ Rotman School of Management, University of Toronto, 105 St. George St., Toronto, ON M5S 3E6, Canada; ${ }^{2}$ Adam Smith Business School, University of Glasgow, Glasgow, Scotland, UK; ${ }^{3}$ School of Business and Management, Lappeenranta University of Technology, Lappeenranta, Finland; ${ }^{4}$ Alliance Manchester Business School, University of Manchester, Manchester, UK
}

Correspondence:

AR Reuber, Rotman School of Management, University of Toronto, 105 St. George St., Toronto, ON M5S 3E6, Canada. Tel: 416-978-5705; e-mail: reuber@rotman.utoronto.ca

\begin{abstract}
Categorizations emphasizing the earliness of internationalization have long been a cornerstone of international entrepreneurship research. Here we contend that the prominence of categories has not been commensurate with theory development associated with them. We draw on categorization theory to explain why earliness-based categories are persistent, and argue that a greater focus on notions related to opportunity can open new avenues of research about the entrepreneurial internationalization of business. We propose and discuss three directions for opportunity-based research on entrepreneurial internationalization, involving context, dynamics and variety.
\end{abstract}

Journal of International Business Studies (2017) 48, 4I I-422. doi: | 0. I 057/s4 I 267-0 I 7-0070-3

Keywords: internationalization theories foreign market entry; context analysis; business dynamics; categorization theory; international new venture; born global; opportunity

\section{INTRODUCTION}

Categories have long been a cornerstone of international entrepreneurship scholarship. A general contention is that this research domain started with the observation that some firms were able to internationalize earlier and faster than existing theory would predict (Oviatt \& McDougall, 1994; McDougall, Shane, \& Oviatt, 1994). The identification of, and explanation for, this new category of firm - labelled "international new venture" - has sparked countless research studies, and Oviatt and McDougall were awarded the JIBS Decade Award in 2004. A decade later, Knight and Cavusgil (2004) examined the capabilities of early internationalizing firms - which they labelled "born globals" - and this also inspired a large body of research and a JIBS Decade Award, in 2014. Since then, a number of narrower firm-level classifications reflecting internationalization patterns have been described in the research literature, including born-again globals (Bell, McNaughton, \& Young, 2001), born regionals (Baum, Schwens, \& Kabst, 2015; Lopez, Kundu, \& Ciravegna, 2009) and geographically focused born-internationals (Kuivalainen, Saarenketo, \& Puumalainen, 2012).

These categories have been important in providing labels to delineate different temporal and spatial dimensions of the
Received: 8 February 2017

Revised: 8 February 2017

Accepted: 10 February 2017

Online publication date: 27 March 2017 
initiation of internationalization. Their pervasive presence in academic journals, teaching material and policy reports attests to their value in this regard, as does their prominence in recent reviews of the domain (e.g., Jones, Coviello, \& Tang, 2011; Knight \& Liesch, 2016). However, we believe that theory development in this area has not grown commensurately. We think that it may have been constrained by the persistence of existing categories that emphasize the earliness of internationalization, and that new possibilities for theory development will emerge when scholars look beyond this dimension. Our objective here is to outline three such possibilities. To begin with, however, we first draw on categorization theory to explain why existing categories are persistent and constrain new kinds of sensemaking about international entrepreneurship phenomena.

\section{CATEGORIES IN INTERNATIONAL ENTREPRENEURSHIP RESEARCH}

Categorizing things with respect to their similarities and differences is an inherent part of the human condition. It is a basic mechanism that people use to make sense of a messy world and communicate it to others. Indeed, category-based processing is the dominant way to learn about new entities (Fiske \& Neuberg, 1990). For example, when someone goes to a new film, that person is likely to make sense of it by categorizing it into a familiar genre (Hsu, Hannan, \& Koçak, 2009). In the same way, categorization is a basic building block of theory generation. As scholars observe phenomena in their research domain, they automatically compare them to known categories. When an anomaly is encountered - something that does not fit known categories - there is an opportunity to create a new category and develop theory to explain the new phenomenon (Christensen, 2006). This recognition of anomalies is consistent with Oviatt and McDougall's description of how they became interested in theorizing about international new ventures, which occurred when they found it hard to integrate into their existing frameworks the growing number of such firms they observed or read about in the business press (Oviatt \& McDougall, 2005, pp. 3-4).

In order to understand the role of categories in extant international entrepreneurship research, it is important to understand why our existing timingbased categorical schemes are persistent. Categorization theory provides a three-fold explanation.
The first reason has to do with category labels. Since category labels serve to aid in collective sensemaking about the category, successful labels convey both the novelty of a category and its differences with existing categories (Grodal, Gotsopoulos, \& Suarez, 2015). For example, the labels "international new venture" and "born global firm" both emphasize the earliness of internationalization of these firms compared with other types of firms, through the words "new" and "born." Successful category labels introduced after a dominant category has emerged tend to highlight the novelty of the new category, but in a manner that links it with existing categories. This is normally done through a process of linguistic recombination: the reformulation of one or more pre-existing words or phonemes to create a new category label (Grodal et al., 2015, p. 426). Again, this practice has been common in the international entrepreneurship literature; for instance, the category labels "born again global" and "born regional" are both linguistic reformulations of "born global." The advantage of such reformulated categories is that they are easy to remember and communicate. However, the drawback is that categorical variations highlight one aspect of an entity while ignoring others. In this case, initial category labels were based on the relationship between internationalization and firm age at the initiation of internationalization. Later labels tended to retain "age" as the familiar, with novelty introduced as variants. For example, labels for spatially-based patterns like "born regionals" were tethered to temporally-based stems.

The second reason for category persistence in international entrepreneurship is that the rules governing category inclusion and exclusion in this research area tend to be "lenient." Categories that are more lenient allow greater flexibility with respect to inclusion than categories that are less lenient; in other words, category boundaries are more porous (Pontikes \& Barnett, 2015). Lenient categories are attractive for producers - and presumably for scholars as knowledge producers because they can accommodate a greater range of fit (Pontikes \& Barnett, 2015). We believe that leniency is attractive to international entrepreneurship researchers because it enables categories to apply to very different contexts. For example, although the "born global" category includes firms characterized by early and rapid internationalization in a broad sense (Cavusgil \& Knight, 2015), the operational criteria defining inclusion in the category vary considerably (Coviello, 2015). Studying 
Chinese "born global" firms, Zhou, Wu, and Luo (2007) included only small- and medium-sized enterprises that initiated some internationalization activities (including importing) within three years of start-up, and which had achieved at least $10 \%$ of sales from exporting. Studying Canadian "born global" firms, Sui and Baum included only smalland medium-sized enterprises that exported within two years of start-up and had achieved at least 25\% of sales to "global (non-US) markets" during the first year of export activity (Sui \& Baum, 2014, p. 828). Studying firms in the passenger airline industry, Fan and Phan define a "born global" firm as "one that allocates at least $20 \%$ of its inaugural production capacity to international markets at inception" (Fan \& Phan, 2007, p. 1116). Moreover, many firms labelled "born global" exhibit little international diversification with respect to geographic, economic, institutional and cultural diversity, and so may experience little of the often considerable challenges associated with such diversity (Verbeke, Zargarzadeh, \& Osiyevskyy, 2014). The advantage of such leniency in operational definitions is that it accommodates the considerable variation across research contexts. However, drawbacks of this leniency are greater difficulty in comparing findings across studies, and evasion of the questioning and revision of existing categories.

The third reason for the persistence of categories in international entrepreneurship is that they draw attention to - and give legitimacy to - entities inside known categories. This tendency is referred to as the categorical imperative (Schneiberg \& Berk, 2010; Zuckerman, 1999). The categorical imperative may result in entities outside known categories being overlooked, which can obscure recognition of the anomalies that trigger the definition of new categories. Consistent with this logic, Oviatt and McDougall, when describing their growing attention to international new ventures, note general disinterest in such ventures in these terms: "A few academic scholars also noticed and studied them; however, more often, such firms were regarded as uninteresting anomalies" (Oviatt \& McDougall, 2005 , p. 3). Another danger of the categorical imperative is that it can yield pressures for conformity to known categorizations and penalties for deviance, and this can compel scholars building on prior research to adopt the categories identified in prior research. For example, Schneiberg and Berk argue that once categories are in place, "debates, deliberation, and struggles with novelty - all the work of category revision, experimentation, and redefinition - more or less cease, receding into the background as the exception rather than the rule" (Schneiberg \& Berk, 2010, p. 287).

Thus categorization theory explains the persistence of existing categories. Applied to international entrepreneurship research, it explains why there is a persistent categorization of firms on the basis of early internationalization: when new firms first enter foreign markets and/or when they achieve a certain level of internationalization in terms of sales and/or geographic scope. However, we contend that new possibilities for research will emerge when scholars look beyond categorization based on considerations associated with "earliness." Specifically, we outline three possible directions for future research.

Underlying these possibilities is Oviatt and McDougall's broader conceptualization of entrepreneurial internationalization, which is based on the pursuit of opportunity: "the discovery, enactment, evaluation, and exploitation of opportunities - across national borders - to create future goods and services" (Oviatt \& McDougall, 2005:7). In building on this conceptualization, we recognize that multiple definitions of "opportunity" exist (e.g., Mainela, Puhakka, \& Servais, 2014). Definitions in entrepreneurship tend to conceptualize opportunities as situations where it is possible to introduce something new to a market (Alvarez, Barney, \& Anderson, 2013; Shane \& Venkataraman, 2000), while definitions in international business tend to conceptualize opportunities as situations where it is possible to enter new foreign markets (e.g., Ellis, 2011; Johanson \& Vahlne, 2009; Santangelo \& Meyer, 2011). To avoid prioritizing either research tradition, we define opportunity broadly as "a time, condition, or set of circumstances permitting or favorable to a particular action or purpose" (Oxford English Dictionary, 2014). We now outline three new research directions based on this definition, embracing context, dynamics and variety. The discussion is summarized in Table 1.

\section{DIRECTION 1: INCORPORATING CONTEXT}

Categorizations based on early internationalization tend to be "acontextual," in that they are often assumed to be unvarying across different research contexts. In practice, categorical boundaries do vary contextually, as discussed above, when different researchers operationalize category boundaries 
Table 1 Research possibilities related to an opportunity-focused study of entrepreneurial internationalization

Research emphasis

Context Studying how situational features influence the perception and pursuit of international opportunities

Dynamics Studying the perception and pursuit of international opportunities as dynamic phenomena

Variety Studying greater variety in the actors pursuing international opportunities and the processes used to pursue them
Research directions related to the perception and pursuit of international opportunities

Studying how the perception and pursuit of opportunities affect, and are affected by, factors at other levels of analysis

Studying how sociocultural and sociolinguistic differences in the theoretical constructs related to opportunities affect the ways they are perceived and pursued

Studying how temporal dimensions of opportunities affect the ways they are perceived and pursued

Studying how events affect the ways that opportunities are perceived and pursued

Studying the perception and pursuit of opportunities as events with duration, which may involve foreign market creation

Studying the perception and pursuit of opportunities as sequences of duration events over time

Studying how organizational and inter-organizational practices and routines affect and are affected by, the perception and pursuit of opportunities

Studying how the perception and pursuit of opportunities may stabilize, destabilize and restabilize organizations

Studying the perception and pursuit of opportunities by market actors in sectors, and with attributes, that are less frequently associated with internationalization

Studying imitation and innovation in the perception and pursuit of international opportunities over time and context

Studying why and when different ways of perceiving and pursuing internationalization opportunities result in similarly effective outcomes in different ways. However, we believe that there is greater scope to contextualize international entrepreneurship theoretically.

Contextualizing research means specifying how situational features influence the occurrence or meaning of the phenomenon under study (Bamberger, 2008; Johns, 2006). For both inductive qualitative research and deductive quantitative research, contextualizing a study is important in delineating the boundaries of the theoretical claims made (Cuervo-Cazurra, Andersson, Brannen, Nielsen, \& Reuber, 2016). Contextualization is particularly relevant for international business research: context is inherent to internationalization and so theories have to be sensitive to different contexts (Welch, Piekkari, Plakoyiannaki, \& PaavilainenMäntymäki, 2011). Moreover, research adopting an opportunity-based view of entrepreneurial behavior necessarily needs to be contextualized because opportunities are inherently contextual: based in a "time, condition, or set of circumstances," as defined above. In this section we outline suggestions for the contextualization of future internationalization research, and organize our discussion by three dimensions of context identified by Johns (2006). In doing so, we note that there is close co-existence and co-evolution among these dimensions, with the cross-level dimension, which is discussed first, typically being present and interacting with the other dimensions.

A cross-level effect is the dimension of context most often used in international business research: theoretical constructs at one level of analysis affect those at another. Much of this research examines higher level influences on lower level phenomena. For example, Baker, Gedajlovic and Lubatkin (2005) develop a conceptual framework describing how and why processes underlying the pursuit of entrepreneurial opportunities vary across countries. In empirical research, scholars have shown that environmental-level factors explain patterns in the internationalization of young firms (e.g., Fan \& Phan, 2007; Fernhaber, Gilbert, \& McDougall, 2008; Mudambi \& Zahra, 2007) and that institutional features influence the types of opportunities pursued by entrepreneurs and their capital providers, as well as how they are pursued (e.g. Ault, 2016; Bowen \& De Clercq, 2008; Guler \& Guillén, 2010). 
Under-explored to date is the possibility that the pursuit of opportunities may impact higherlevel factors such as institutional characteristics. This possibility has been highlighted in recent entrepreneurship research, which shows how actions by entrepreneurial people and organizations result in institutional changes. For example, Alvarez, Young and Woolley (2015) show how an entrepreneur's pursuit of a commercial opportunity in the king crab industry involved the development of industry standards and regulations. Another example is Vaaler's analysis of how immigrant remittances can affect country-level attributes like startup rates, capital availability and openness to international trade (Vaaler 2011). Given the imitation among geographically adjacent firms in pursuing international opportunities (e.g., Fernhaber \& Li, 2010), an important research question for scholars is whether and how firms that pursue international opportunities may change the nature of their local or regional context.

Contextual variation in entrepreneurial processes has been studied across countries to a greater extent than across industries, and a focus on industries is likely to yield valuable insights on how firms pursue international opportunities. For example, one way to characterize an industry is whether it is global or multidomestic (Kobrin, 1991; Porter, 1986). Since global industries are characterized by high R\&D requirements, worldwide technological standards and minimal market barriers, and multidomestic industries are characterized by high market barriers such as country-specific regulations, and consumer tastes and preferences, one would expect that processes involved in the pursuit of opportunities would differ between them.

A second dimension of context identified by Johns (2006) is context as a shaper of meaning: a seemingly similar theoretical construct may have different meanings in different contexts. For instance, while we know that social and business networks are important in the pursuit of international opportunities (Coviello, 2006; Johanson \& Vahlne, 2009), we have little understanding of how aspects of social networks theoretically relevant to the pursuit of opportunity vary contextually. As an example, the granting of favors varies substantially among the Brazilian jeitinho, the Chinese quanxi and the Russian blat, and it is therefore important to examine the similarities and differences in how these "favors trading" practices are embedded in opportunity-related processes. In order to do so, scholars will need to design studies and research teams that take into account contextualized sociocultural and sociolinguistic differences in underlying theoretical constructs (e.g., Chidlow, Plakoyiannaki, \& Welch, 2014; Kuznetsov \& Kuznetsova, 2014).

The entrepreneurship literature suggests that another way in which context shapes meaning is through the dimension of time (Short, Ketchen, Shook, \& Ireland, 2010). Given that opportunities are time-dependent, the temporal dimensions of opportunities are likely to affect both how they are perceived and the actions used to pursue them. Opportunities in foreign markets may be temporally constrained by situational factors such as the availability of local partners and the transient nature of host government incentives (e.g., Sarkar, Cavusgil, \& Aulakh, 1999), or they may become pressing because of situational factors. For example, Michael-Tsabari, Labaki and Zachary (2014) report that the search for foreign opportunities can be sparked by the fear that impending domestic legislation will open the door to foreign competitors. More fundamentally, entrepreneurs select exchange partners with temporal orientations similar to their own (Fischer, Reuber, Hababou, Johnson, \& Lee, 1997) and there may be differing temporal orientations across countries that affect the pursuit of international opportunities (see Reinecke \& Ansari, 2015). While international entrepreneurship researchers have studied temporality with respect to when foreign market entries are made, there has been little study, to our knowledge, of the temporal orientations of internationalizing firms, how their decision-makers perceive the windows of opportunities and how the opportunity-based processes they follow take these windows into consideration.

A third dimension of context is related to the impact of "events" (Johns, 2006). Events can punctuate the status quo, thereby opening up or shutting down opportunities. There are a host of individual-level, firm-level events and institutional-level events that can affect firms - for example, foreign travel, a change in leadership, a merger or acquisition, a change in government, a devaluation of currency, or the establishment of (or withdrawal from) a trade agreement - and these may lead to perceptions that the pursuit of a particular opportunity is more or less favorable. Entrepreneurship research suggests that even high profile firm-level successes and failures constitute vital events that signal the quality of subsequent opportunities (Pontikes \& Barnett, 2015). 
Moreover, opportunities can appear as serendipitous events (Dew, 2009), and apart from recognizing that serendipity plays a role in the pursuit of international opportunities (Crick \& Spence, 2005), we know little about the contextual factors that influence how firms react to serendipity. A step in this direction is Maitland and Sammartino's (2015) study of how decision-makers responded to the serendipitous opportunity to make an acquisition in a politically hazardous foreign country.

\section{DIRECTION 2: HIGHLIGHTING DYNAMICS}

Categorization captures a snapshot of a firm, in that an entity is classified as a certain type at a particular point in time. For example, a firm can acquire a "born global" label if specified milestones are achieved in a specified time period, and this category label is never withdrawn. Conversely, a firm will never be labelled as "born global" if these milestones are not achieved, no matter what the firm's achievements are after this time period. As members of an age-based category change post-categorization, category membership becomes increasingly heterogeneous over time and the criteria that led to category inclusion are likely to become less relevant to subsequent outcomes. Such static categorization schemes do not reflect the fact that internationalization and the pursuit of opportunities are both inherently dynamic phenomena. Neglecting explicit study of these dynamics may constrain our understanding of important phenomena. Consistent with a focus on earliness, extant international entrepreneurship research concerned with dynamics has tended to focus on the time to entry (e.g., Casillas \& Acedo, 2013; Prashantham \& Young, 2009). In this section we identify four alternate meanings of "dynamics," each explicitly associated with an opportunity-based perspective on entrepreneurial internationalization.

First, the pursuit of an opportunity does not necessarily occur instantaneously at a point in time, but can be conceptualized as an event with duration. Johanson and Vahlne (2009) contend that foreign market opportunities should be conceptualized as position-building processes involving learning, trust and commitment and lasting as long as five years. Santangelo and Meyer (2011) show that positionbuilding processes are not necessarily continuous and there can be post-entry adjustments to a firm's commitment to a market opportunity. Teece (2014) argues that the pursuit of market opportunities may not be merely a recognition and assessment activity; when foreign markets do not exist for a firm's products and services, they need to be created and this involves building a supportive market ecosystem. Thus scholars should not only consider firmlevel internationalization as an event with duration, but should also consider foreign market creation as an important outcome to be explained. Entrepreneurship research on the creation of new markets offers important insights in this regard (e.g., Navis \& Glynn, 2010; Santos \& Eisenhardt, 2009).

Second, firms are likely to pursue multiple opportunities over time. This means that the outcomes of recognizing and pursuing one opportunity become the antecedents of the recognition and pursuit of subsequent opportunities (Jones \& Coviello, 2005). For example, international experience and international networks, often conceptualized as antecedents of foreign market entry, can change as international activities are conducted and so may be viewed as both antecedents and outcomes of internationalization. There are varied sequences through which opportunities are pursued (Kuivalainen, Sundqvist, Saarenketo, \& McNaughton, 2012; Mathews \& Zander, 2007) and these sequences are consequential to important outcomes. For example, perceptions about opportunities (foreign market entries) are affected by network development in, and learning from, past opportunities (market entries) pursued (Bingham, 2009; Bingham \& Davis, 2012; Chandra, Styles, \& Wilkinson, 2012). Cuervo-Cazurra (2011) reports that managers may select foreign markets explicitly to learn how to manage the complexity associated with subsequent opportunities.

Both of these opportunity-based conceptualizations of the dynamics of internationalization indicate the importance of developing process theory that is "concerned with understanding how things evolve over time and why they evolve in this way" (Langley, 1999, p. 692). Process research tends to examine temporal sequences of events (Langley, 1999) and recent entrepreneurship research has shown how it can be used to understand better the nature of entrepreneurial opportunity (for example, McMullen \& Dimov, 2013; Suddaby, Bruton, \& Si, 2015). However, despite the apparent match between process theory and the dynamics of entrepreneurial internationalization, reviews of opportunity-based research in international entrepreneurship (Mainela et al., 2014) and process-based research in international business (Welch \& Paavilainen-Mäntymäki, 2014) have few empirical studies in common. 
A third conceptualization of dynamics relates to the changes in the processes through which firms pursue opportunities over time. These dynamics are likely to involve path dependencies (Sydow, Schreyögg, \& Koch, 2009) and routines (Prashantham \& Floyd, 2012; Teece, 2014) that develop over time. This happens because effective processes are self-reinforcing and persist. Firms that pursue international opportunities soon after start-up may avoid organizational inertia and enjoy learning advantages of newness rather than liabilities of newness (Autio, Sapienza, \& Almeida, 2000). Further, if early attempts are successful, the processes underlying them are likely to become embodied in stable routines. While this is beneficial if subsequent opportunities are similar, it may be dysfunctional if the firm is unable to meet the environmental demands of substantially different markets. As the organizationenvironment fit decreases, one would expect higher adjustment costs (Hutzschenreuter, Voll, \& Verbeke, 2011), higher transaction costs (Orr \& Scott, 2008), and the liabilities of obsolescence (Sørensen \& Stuart, 2000) to become relevant, hindering the firm's adaptiveness. While there has been some theoretical development in this area, there remain many process-related questions associated with the entanglement of practices and the pursuit of international opportunities.

Fourth, the pursuit of opportunities can be a process that upsets the status quo, thereby being destabilizing. Consistent with the notion from entrepreneurship that the pursuit of entrepreneurial opportunities can be disruptive (Schumpeter, 1943), Mathews and Zander view the recognition and exploitation of international opportunities as "disequilibrium-oriented" (Mathews \& Zander 2007: 392). Destabilization is also likely to be relevant at the firm level: internationalization is often sporadic (Kuivalainen et al., 2012a) and there is a high rate of foreign market exit (Bernard \& Jensen, 2004). A firm's resources and capabilities may be insufficient to overcome the discontinuity associated with foreign market opportunities, and to deal with the concomitant unexpected risks and costs (Crick, 2004; Mathews \& Zander, 2007). We know little about the processes involved with the destabilization and subsequent restabilization involved in the pursuit of opportunities. Reuber (2016) argues for focusing on the destabilization and restabilization of a firm's logics and routines in this respect. Since early and frequent experience with an organizational change increases its reoccurrence (Amburgey, Kelly, \& Barnett, 1993), the destabilization associated with the pursuit of international opportunities is likely to be more severe when internationalization occurs rarely and later in a firm's existence. Yet we have little understanding of how older internationalizers overcome domestic path dependencies (see Autio, 2005) and why some firms reinternationalize after withdrawal while others do not (Crick, 2004; Welch \& Welch, 2009).

Research on international business processes tends to consist of either deductive variance-based inquiries with respect to which processes are used by firms with differing characteristics (e.g., CuervoCazurra, 2011) or inductive qualitative studies about processes not yet reported in the research literature (e.g., Bingham, 2009). Another methodological option for scholars interested in studying processes related to entrepreneurial internationalization is simulation. A simulation is a model of system behavior, executed experimentally through computer software. As a research method, it is partially deductive, in that outcomes follow from the assumptions made, and partially inductive, in that the relationships among theoretical constructs is inferred from analyzing the outcomes (Harrison, Lin, Carroll, \& Carley, 2007). Simulation is not yet widely used in international business research but has promise for understanding dynamics. For example, Davis, Eisenhardt and Bingham (2007) illustrate how simulation has been used to address research questions related to some of the processes that have been identified as key to understanding entrepreneurial internationalization, such as change and inertia, replication and imitation, exploitation and exploration, and learning.

\section{DIRECTION 3: INCREASING VARIETY}

As discussed above, the categorization imperative (Zuckerman, 1999) draws attention to entities within existing categories. We believe that the focus on firms in familiar categories has had a homogenizing effect on the types of firms examined in studies of entrepreneurial internationalization, and contend that it is important for scholars to investigate a greater variety of phenomena related to the pursuit of international opportunities. In this section we consider two types of variety.

One type of variety relates to the nature of the firms being studied. Well-known theories of international business, such as the eclectic paradigm and internalization theory emphasize variation among internationalizing firms (e.g., Buckley \& Casson, 2009; Dunning, 2009; Rugman \& 
Verbeke, 2008). However, extant research on entrepreneurial internationalization tends to highlight firms that tend to internationalize more: product-based firms rather than service-based firms, knowledge-intensive firms rather than firms in traditional sectors, and resource-constrained firms that internationalize by exporting rather than through higher commitment modes (e.g., Dimitratos, Amorós, Etchebarne, \& Felzensztein, 2014). Indeed, Hennart (2014) argues that studies of early internationalizing firms focus on firms whose business models facilitate quick internationalization. As a result, we have less understanding of how variation across diverse firms impacts the pursuit of international opportunities than we have about variation within frequently studied sectors. For example, if low tech firms and high tech firms are characterized by different levels and types of asset specificity, appropriability and transaction costs, then there is likely to be variation in what types of opportunities are most favorable to them. This lack of attention to the diversity in the firms studied has also recently been recognized and decried in the entrepreneurship field (e.g., Welter, Baker, Audretsch, \& Gartner, 2016).

National figures suggest that internationalization of any business is, if not a rare event, then an uncommon one. Fewer than 8\% of Australian businesses sell outside of Australia (Australian Bureau of Statistics, 2014). Fewer than 1\% of American businesses export, and of those, 58\% export to only one country (International Trade Administration, 2017). National figures also suggest that internationalization is particularly uncommon in the absence of free trade agreements. For example, while $10 \%$ of German SMEs export within the European Union, only $2 \%$ export outside it (European Commission, 2012, pp. 10, 13). The numbers for the United Kingdom are about double those for Germany but still low, with 20\% of British SMEs exporting within the European Union but only 5\% exporting outside it (House of Lords, 2013, p. 20). Therefore, it may be fruitful to focus research attention on sectors where internationalization is less common. In doing so, researchers will likely want to pay attention to unrepresentative or extreme firms. Analyzing average firms in sectors with a low base rate of internationalization, using large-scale quantitative methods, may be uninteresting because the average firm is uninteresting. Instead, detailed case studies of extreme cases can provide insights as to how and why these firms are unrepresentative (Chen, 2015; Siggelkow, 2007; Yin, 2009).

A second type of variety relates to the processes used to pursue international opportunities and how they vary over time and experience, and across different types of firms. For example, the behaviors that are most effective and growth-oriented may change as firms age and become more internationalized (e.g., Gabrielsson, Gabrielsson, \& Dimitratos, 2014). As another example, firms may benefit differentially from a regional strategy or a global strategy (e.g., Banalieva \& Eddleston, 2011). There may also be variance with respect to perceptions of opportunities: the entrepreneurship literature points out that decision-makers perceive market opportunities imitatively or innovatively and this affects the way that a firm enters a market (Cliff, Jennings, \& Greenwood, 2006). The reporting of imitative behavior in internationalization among resourceconstrained firms (e.g., Fernhaber \& Li, 2010; Oehme $\&$ Bort, 2015) suggests that small and young firms may be able to pursue international opportunities in ways that do not require the highly innovative behavior and risk-taking attitudes that have been linked to internationalization in studies of entrepreneurial orientation (see Brouthers, Nakos, \& Dimitratos, 2014; Covin \& Miller, 2014).

Further, we know from current literature that a variety of internationalization trajectories or paths are followed (e.g., Kuivalainen et al., 2012b). This literature has emphasized that different paths lead to different outcomes. What has been under-theorized is whether different paths can lead to the same outcome. For example, a typology, such as the Miles and Snow (1978) typology in strategic management, is a theoretical statement of how different organizational attributes co-occur (Bailey, 1994; Doty \& Glick, 1994; Fiss, 2011). There are multiple paths, but each path results in high organizational effectiveness, or "fit." In order to provide an enhanced understanding of the variety inherent in entrepreneurial internationalization, scholars could develop theoretically grounded typologies about how diverse firms may pursue international opportunities in different - but effective - ways. An inductive empirical method appropriate to this type of inquiry is fuzzy set/ Qualitative Comparative Analysis (fs/QCA) (Fiss, 2011), which has been used to study configurations of effective corporate governance mechanisms (Misangyi \& Acharya, 2014), corporate adaptation processes (Vergne \& Depeyre, 2016) and barriers to imitation in a global industry (Kim, 2013). 


\section{CONCLUSIONS}

Our central theme is that the development of theory about entrepreneurial internationalization will be well-served by studying the phenomenon in its diverse manifestations. While advances have certainly been made in understanding why and how firms internationalize soon after start-up, we contend that theory development is constrained by focusing on "earliness." We see possibilities for new research questions opening up with a broader definition of entrepreneurial internationalization, focused on the pursuit of opportunity. In particular, as detailed here, we encourage international business scholars to formulate novel research questions that explore the contexts, the dynamics and the variety of entrepreneurial internationalization. By highlighting several new methods that are not often used in international entrepreneurship research, we also hope to encourage scholars to diversify the tools and techniques they use.

In advocating for opportunity-based research, we wish to make it clear that we do not aim to substitute the straitjacket of "early" for the straitjacket of "opportunity." We are very aware that "entrepreneurial opportunity" is an elusive concept (Dimov, 2011), which has been defined in many different ways (e.g., Davidsson, 2015). We have opted for a very broad definition for this discussion, and encourage researchers to define what is meant by opportunity in their own research projects, including whether they see them as being recognized, evaluated, created, explored, exploited, or something else. While some might view this disorderliness as undesirable and leading to the

\section{REFERENCES}

Alvarez, S. A., Barney, J. B., \& Anderson, P. 2013. Forming and exploiting opportunities: The implications of discovery and creation processes for entrepreneurial and organizational research. Organization Science, 24(1): 301-317.

Alvarez, S. A., Young, S. L., \& Woolley, J. L. 2015. Opportunities and institutions: A co-creation story of the king crab industry. Journal of Business Venturing, 30(1): 95-112.

Amburgey, T. L., Kelly, D., \& Barnett, W. P. 1993. Resetting the clock: The dynamics of organizational change and failure. Administrative Science Quarterly, 38(1): 51-73.

Ault, J. K. 2016. An institutional perspective on the social outcome of entrepreneurship: Commercial microfinance and inclusive markets. Journal of International Business Studies, 47(8): 951-967.

Australian Bureau of Statistics. 2014. Table 8167.0 - Selected characteristics of Australian businesses. http://www.abs.gov.au/ ausstats/abs@.nsf/Latestproducts/8167.0Main\%20Features32012 -13 ?opendocument $\&$ tabname $=$ Summary $\&$ prodno $=8167$. 0\&issue=2012-13\&num=\&view, accessed 6 March 2015. fragmentation of research conversations, we think that the creative destruction of persistent patterns by innovative researchers can yield important insights for our understanding of what it means to internationalize entrepreneurially.

In closing, we recognize Toni Morrison's caution that definitions belong to the definer, not the defined (Morrison, 1987, p. 190). We put firms in categories; they are not inherently located there. With this in mind, we point out that an important element of the research process is the observation of an anomaly that does not fit existing frameworks and theories. Such anomalies are likely to be prevalent in the highly-connected world we live in, with its fast-changing political, social, economic, physical and technological landscapes. In order to understand entrepreneurial behavior and outcomes amidst such change, it is critical that international business scholars question existing categorizations, and actively seek out and study anomalies.

\section{ACKNOWLEDGEMENTS}

The authors are grateful for the valuable comments on earlier versions of these ideas from Christian Schwens, Sui Sui, Alain Verbeke, participants of the 2015 European International Business Academy, participants of the 2016 AIB-UKI conference, and two anonymous reviewers. The research assistance of Cassandra Nakamura and lan Thomson is acknowledged with many thanks.

Autio, E. 2005. Creative tension: The significance of Ben Oviatt's and Patricia McDougall's article 'toward a theory of international new ventures'. Journal of International Business Studies, 36(1): 9-19.

Autio, E., Sapienza, H. J., \& Almeida, J. G. 2000. Effects of age at entry, knowledge intensity, and imitability on international growth. Academy of Management Journal, 43(5): 909-924.

Bailey, K. D. 1994. Typologies and taxonomies: An introduction to classification techniques. Thousand Oaks, CA: Sage.

Baker, T., Gedajlovic, E., \& Lubatkin, M. 2005. A framework for comparing entrepreneurship processes across nations. Journal of International Business Studies, 36(5): 492-504.

Bamberger, P. 2008. Beyond contextualization: Using context theories to narrow the micro-macro gap in management research. Academy of Management Journal, 51(5): 839-846.

Banalieva, E. R., \& Eddleston, K. A. 2011. Home-region focus and performance of family firms: The role of family vs. nonfamily leaders. Journal of International Business Studies, 42(8): 1060-1072. 
Baum, M., Schwens, C., \& Kabst, R. 2015. A latent class analysis of small firms' internationalization patterns. Journal of World Business, 50(4): 754-768.

Bell, J., McNaughton, R., \& Young, S. 2001. 'Born-again global' firms: An extension to the 'born global' phenomenon. Journal of International Management, 7(3): 173-189.

Bernard, A. B., \& Jensen, J. B. 2004. Why some firms export. Review of Economics and Statistics, 86(2): 561-569.

Bingham, C. B. 2009. Oscillating improvisation: How entrepreneurial firms create success in foreign market entries over time. Strategic Entrepreneurship Journal, 3(4): 321-345.

Bingham, C. B., \& Davis, J. P. 2012. Learning sequences: Their existence, effect, and evolution. Academy of Management Journal, 55(3): 611-641.

Bowen, H. P., \& De Clercq, D. 2008. Institutional context and the allocation of entrepreneurial effort. Journal of International Business Studies, 39(4): 747-767.

Brouthers, K. D., Nakos, G., \& Dimitratos, P. 2014. SME entrepreneurial orientation, international performance, and the moderating role of strategic alliances. Entrepreneurship Theory and Practice, 39(5): 1161-1187.

Buckley, P. J., \& Casson, M. C. 2009. The internalization theory of the multinational enterprise: A review of the progress of a research agenda after 30 years. Journal of International Business Studies, 40(9): 1563-1580.

Casillas, J. C., \& Acedo, F. J. 2013. Speed in the internationalization process of the firm. International Journal of Management Reviews, 15(1): 15-29.

Cavusgil, S. T., \& Knight, G. 2015. The born global firm: An entrepreneurial and capabilities perspective on early and rapid internationalization. Journal of International Business Studies, 46(1): 3-16.

Chandra, Y., Styles, C., \& Wilkinson, I. E. 2012. An opportunitybased view of rapid internationalization. Journal of International Marketing, 20(1): 74-102.

Chen, K. K. 2015. Using extreme cases to understand organizations. In K. Elsbach \& R. M. Kramer (Eds.), Handbook of qualitative organizational research: Innovative pathways and methods: 33-44. New York, NY: Routledge.

Chidlow, A., Plakoyiannaki, E., \& Welch, C. 2014. Translation in cross-language international business research: Beyond equivalence. Journal of International Business Studies, 45(5): 562-582.

Christensen, C. M. 2006. The ongoing process of building a theory of disruption. Journal of Product Innovation Management, 23(1): 39-55.

Cliff, J. E., Jennings, P. D., \& Greenwood, R. 2006. New to the game and questioning the rules: The experiences and beliefs of founders who start imitative versus innovative firms. Journal of Business Venturing, 21(5): 633-663.

Coviello, N. E. 2006. The network dynamics of international new ventures. Journal of International Business Studies, 37(5): 713-731.

Coviello, N. E. 2015. Re-thinking research on born globals. Journal of International Business Studies, 46(1): 17-26.

Covin, J. G., \& Miller, D. 2014. International entrepreneurial orientation: Conceptual considerations, research themes, measurement issues, and future research directions. Entrepreneurship Theory and Practice, 38(1): 11-44.

Crick, D. 2004. UK SMEs' decision to discontinue exporting: An exploratory investigation into practices within the clothing industry. Journal of Business Venturing, 19(4): 561-587.

Crick, D., \& Spence, M. 2005. The internationalisation of 'high performing' UK high-tech SMEs: A study of planned and unplanned strategies. International Business Review, 14(2): 167-185.

Cuervo-Cazurra, A. 2011. Selecting the country in which to start internationalization: The non- sequential internationalization model. Journal of World Business, 46(4): 426-437.

Cuervo-Cazurra, A., Andersson, U., Brannen, M. Y., Nielsen, B. B., \& Reuber, A. R. 2016. From the editors: Can I trust your findings? Ruling out alternative explanations in international business research. Journal of International Business Studies, 47(8): 881-897.

Davidsson, P. 2015. Entrepreneurial opportunities and the entrepreneurship nexus: A re-conceptualization. Journal of Business Venturing, 30(5): 674-695.

Davis, J. P., Eisenhardt, K. M., \& Bingham, C. B. 2007. Developing theory through simulation methods. Academy of Management Review, 32(2): 480-499.

Dew, N. 2009. Serendipity in entrepreneurship. Organization Studies, 30(7): 735-753.

Dimitratos, P., Amorós, J. E., Etchebarne, M. S., \& Felzensztein, C. 2014. Micro-multinational or not? International entrepreneurship, networking and learning effects. Journal of Business Research, 67(5): 908-915.

Dimov, D. 2011. Grappling with the unbearable elusiveness of entrepreneurial opportunities. Entrepreneurship Theory \& Practice, 35(1): 57-81.

Doty, D. H., \& Glick, W. H. 1994. Typologies as a unique form of theory building: Toward improved understanding and modeling. Academy of Management Review, 19(2): 230-251.

Dunning, J. H. 2009. Location and the multinational enterprise: John Dunning's thoughts on receiving the Journal of International Business Studies 2008 Decade Award. Journal of International Business Studies, 40(1): 20-34.

Ellis, P. D. 2011. Social ties and international entrepreneurship: Opportunities and constraints affecting firm internationalization. Journal of International Business Studies, 42(1): 99-127.

European Commission. 2012. SBA fact sheet 2012 - Germany. http://ec.europa.eu/enterprise/policies/sme/facts-figures-analysis/ performance-review/files/countries-sheets/2012/germany_en. pdf, accessed 6 March 2015.

Fan, T., \& Phan, P. 2007. International new ventures: Revisiting the influences behind the 'born-global' firm. Journal of International Business Studies, 38(7): 1113-1131.

Fernhaber, S. A., \& Li, D. 2010. The impact of interorganizational imitation on new venture international entry and performance. Entrepreneurship Theory \& Practice, 34(1): 1-30.

Fernhaber, S. A., Gilbert, B. A., \& McDougall, P. P. 2008. International entrepreneurship and geographic location: An empirical examination of new venture internationalization. Journal of International Business Studies, 39(2): 267-290.

Fischer, E., Reuber, A. R., Hababou, M., Johnson, M., \& Lee, S. 1997. The role of socially constructed temporal perspectives in the emergence of rapid-growth firms. Entrepreneurship: Theory and Practice, 22(2): 13-14.

Fiske, S. T., \& Neuberg, S. L. 1990. A continuum of impression formation, from category-based to individuating processes: Influences of information and motivation on attention and interpretation. In M. P. Zanna (Ed.), Advances in experimental social psychology: Vol. 23, pp. 1-74. San Diego, CA: Academic Press.

Fiss, P. 2011. Building better causal theories: A fuzzy set approach to typologies in organization research. Academy of Management Journal, 54(2): 393-420.

Gabrielsson, M., Gabrielsson, P., \& Dimitratos, P. 2014. International entrepreneurial culture and growth of international new ventures. Management International Review, 54(4): $445-471$.

Grodal, S., Gotsopoulos, A., \& Suarez, F. F. 2015. The coevolution of technologies and categories during industry emergence. Academy of Management Journal, 40(3): 423-445.

Guler, I., \& Guillén, M. F. 2010. Home country networks and foreign expansion: Evidence from the venture capital industry. Academy of Management Journal, 53(2): 390-410.

Harrison, J. R., Lin, Z., Carroll, G. R., \& Carley, K. M. 2007. Simulation modeling in organizational and management research. Academy of Management Review, 32(4): 1229-1245.

Hennart, J.-F. 2014. The accidental internationalists: A theory of born globals. Entrepreneurship Theory \& Practice, 38(1): 117-135. 
House of Lords. 2013. Roads to success: SME exports. Report of the Select Committee on Small and Medium Sized Enterprises. HL Paper 131. London: The Stationery Office. http://www.file:/// C:/Users/Becky\%20Reuber/Documents/Family\%20Bus/Texas\% 202015/House\%20of\%20Lords\%20Select\%20Committee\% 20report.pdf, accessed on 6 March 2015.

Hsu, G., Hannan, M. T., \& Koçak, Ö. 2009. Multiple category memberships in markets: An integrative theory and two empirical tests. American Sociological Review, 74(1): 150-169.

Hutzschenreuter, T., Voll, J. C., \& Verbeke, A. 2011. The impact of added cultural distance and cultural diversity on international expansion patterns: A Penrosean perspective. Journal of Management Studies, 48(2): 305-329.

International Trade Administration. 2017. U.S. Department of Commerce. http://www.trade.gov/cs/factsheet.asp. Accessed on February 6, 2017. [query 4]

Johanson, J., \& Vahlne, J.-E. 2009. The Uppsala internationalization process model revisited: From liability of foreignness to liability of outsidership. Journal of International Business Studies, 40(9): 1411-1431.

Johns, G. 2006. The essential impact of context on organizational behavior. Academy of Management Journal, 31(2): 396-408.

Jones, M. V., \& Coviello, N. E. 2005. Internationalisation: Conceptualizing an entrepreneurial process of behaviour in time. Journal of International Business Studies, 36(3): 284-303.

Jones, M. V., Coviello, N. E., \& Tang, Y. K. 2011. International entrepreneurship research (1989-2009): A domain ontology and thematic analysis. Journal of Business Venturing, 26(6): 632-659.

Kim, M. 2013. Many roads lead to Rome: Implications of geographic scope as a source of isolating mechanisms. Journal of International Business Studies, 44(9): 898-921.

Knight, G. A., \& Cavusgil, T. 2004. Innovation, organizational capabilities, and the born-global firm. Journal of International Business Studies, 35(2): 124-141.

Knight, G. A., \& Liesch, P. W. 2016. Internationalization: From incremental to born global. Journal of World Business, 51(1): 93-102.

Kobrin, S. J. 1991. An empirical analysis of the determinants of global integration. Strategic Management Journal, 12(S1): 17-31.

Kuivalainen, O., Saarenketo, S., \& Puumalainen, K. 2012a. Startup patterns of internationalization: A framework and its application in the context of knowledge-intensive SMEs. European Management Journal, 30(4): 372-385.

Kuivalainen, O., Sundqvist, S., Saarenketo, S., \& McNaughton, R. 2012 b. Internationalization patterns of small and mediumsized enterprises. International Marketing Review, 29(5): $448-465$.

Kuznetsov, A., \& Kuznetsova, O. 2014. Building professional discourse in emerging markets: Language, context and the challenge of sensemaking. Journal of International Business Studies, 45(5): 583-599.

Langley, A. 1999. Strategies for theorizing from process data. The Academy of Management Review, 24(4): 691-710.

Lopez, L. E., Kundu, S. K., \& Ciravegna, L. 2009. Born global or born regional? Evidence from an exploratory study in the Costa Rican software industry. Journal of International Business Studies, 40(7): 1228-1238.

Mainela, T., Puhakka, V., \& Servais, P. 2014. The concept of international opportunity in international entrepreneurship: $A$ review and a research agenda. International Journal of Management Reviews, 16(1): 105-129.

Maitland, E., \& Sammartino, A. 2015. Managerial cognition and internationalization. Journal of International Business Studies, 46(7): 733-760.

Mathews, J. A., \& Zander, I. 2007. The international entrepreneurial dynamics of accelerated internationalisation. Journal of International Business Studies, 38(3): 387-403.

McDougall, P. P., Shane, S., \& Oviatt, B. M. 1994. Explaining the formation of international new ventures: The limits of theories from international business research. Journal of Business Venturing, 9(6): 469-487.

McMullen, J. S., \& Dimov, D. 2013. Time and the entrepreneurial journey: The problems and promise of studying entrepreneurship as a process. Journal of Management Studies, 50(8): 1481-1512.

Michael-Tsabari, N., Labaki, R., \& Zachary, R. K. 2014. Toward the cluster model: The family firm's entrepreneurial behavior over generations. Family Business Review, 27(2): 161-185.

Miles, R. E., \& Snow, C. C. 1978. Organizational strategy, structure, and process. New York, NY: McGraw-Hill.

Misangyi, V. F., \& Acharya, A. G. 2014. Substitutes or complements: A configurational examination of corporate governance mechanisms. Academy of Management journal, 57(6): 1681-1705.

Morrison, T. 1987. Beloved. New York, NY: Alfred A. Knopf.

Mudambi, R., \& Zahra, S. A. 2007. The survival of international new ventures. Journal of International Business Studies, 38(2): 333-352.

Navis, C., \& Glynn, M. A. 2010. Legitimate distinctiveness and the entrepreneurial identity: Influence on investor judgments of new venture plausibility. Academy of Management Review, 36(3): 479-499.

Oehme, M., \& Bort, S. 2015. SME internationalization modes in the German biotechnology industry: The influence of imitation, network position, and international experience. Journal of International Business Studies, 46(6): 629-655.

Orr, R. J., \& Scott, W. R. 2008. Institutional exceptions on global projects: A process model. Journal of International Business Studies, 39(4): 562-588.

Oviatt, B. M., \& McDougall, P. P. 1994. Toward a theory of international new ventures. Journal of International Business Studies, 25(1): 45-64.

Oviatt, B. M., \& McDougall, P. P. 2005. The internationalization of entrepreneurship. Journal of International Business Studies, 36(1): 2-8.

Oxford English Dictionary, Third edition, June 2014.

Pontikes, E. G., \& Barnett, W. P. 2015. The persistence of lenient market categories. Organization Science, 26(5): 1415-1431.

Porter, M. 1986. Changing patterns of international competition. California Management Review, 28(2): 9-40.

Prashantham, S., \& Floyd, S. W. 2012. Routine microprocesses and capability learning in international new ventures. Journal of International Business Studies, 43(6): 544-562.

Prashantham, S., \& Young, S. 2009. Post-entry speed of international new ventures. Entrepreneurship Theory \& Practice, 35(2): 275-292.

Reinecke, J., \& Ansari, S. 2015. When times collide: Temporal brokerage at the intersection of markets and developments. Academy of Management Journal, 58(2): 618-648.

Reuber, A. R. 2016. An assemblage-theoretic perspective on the internationalization processes of family firms. Entrepreneurship Theory \& Practice, 40(6): 1269-1286.

Rugman, A. M., \& Verbeke, A. 2008. Internalization theory and its impact on the field of international business. Research in Global Strategic Management, 14: 155-174.

Santangelo, G. D., \& Meyer, K. E. 2011. Extending the internationalization process model: Increases and decreases of MNE commitment in emerging economies. Journal of International Business Studies, 42(7): 894-909.

Santos, F. M., \& Eisenhardt, K. M. 2009. Constructing markets and shaping boundaries: Entrepreneurial power in nascent fields. Academy of Management Journal, 52(4): 643-671.

Sarkar, M. B., Cavusgil, S. T., \& Aulakh, P. S. 1999. International expansion of telecommunication carriers: The influence of market structure, network characteristics, and entry imperfections. Journal of International Business Studies, 30(2): 361-381.

Schneiberg, M., \& Berk, G. 2010. From categorical imperative to learning by categories: Cost accounting and new categorical practices in American manufacturing, 1900-1930. Research in the Sociology of Organizations, 31, 255-292. 
Schumpeter, J. A. 1943. Capitalism, socialism \& democracy. Taylor \& Francis e-Library edition, 2003.

Shane, S., \& Venkataraman, S. 2000. The promise of entrepreneurship as a field of research. Academy of Management Review, 25(1): 217-226.

Short, J. C., Ketchen, D. J., Shook, C. L., \& Ireland, R. D. 2010. The concept of 'opportunity' in entrepreneurship research: Past accomplishments and future challenges. Journal of Management, 36(1): 40-65.

Siggelkow, N. 2007. Persuasion with case studies. Academy of Management Journal, 50(1): 20-24.

Sørensen, J. B., \& Stuart, T. E. 2000. Aging, obsolescence, and organizational innovation. Administrative Science Quarterly, 45(1): 81-112.

Suddaby, R., Bruton, G. D., \& Si, S. X. 2015. Entrepreneurship through a qualitative lens: Insights on the construction and/or discovery of entrepreneurial opportunity. Journal of Business Venturing, 30(1): 1-10.

Sui, A., \& Baum, M. 2014. Internationalization strategy, firm resources and the survival of SMEs in the export market. Journal of International Business Studies, 45(4): 821-841.

Sydow, J., Schreyögg, G., \& Koch, J. 2009. Organizational path dependence: Opening the black box. Academy of Management Review, 34(4): 689-709.

Teece, D. J. 2014. A dynamic capabilities-based entrepreneurial theory of the multinational enterprise. Journal of International Business Studies, 45(1): 8-37.

Vaaler, P. M. 2011. Immigrant remittances and the venture investment environment of developing countries. Journal of International Business Studies, 42(9): 1121-1149.

Verbeke, A., Zargarzadeh, M. A., \& Osiyevskyy, O. 2014. Internalization theory, entrepreneurship and international new ventures. Multinational Business Review, 22(3): 246-269.

Vergne, J.-P., \& Depeyre, C. 2016. How do firms adapt? A fuzzyset analysis of the role of cognition and capabilities in US defense firms' responses to 9/11. Academy of Management Journal, 59(5): 1653-1680.

Welch, C., \& Paavilainen-Mäntymäki, E. 2014. Putting process (back) in: Research on the internationalization process of the firm. International Journal of Management Reviews, 16(1): $2-23$.

Welch, C., \& Welch, L. S. 2009. Re-internationalisation: Exploration and conceptualization. International Business Review, 18(6): 567-577.

Welch, C., Piekkari, R., Plakoyiannaki, E., \& PaavilainenMäntymäki, E. 2011. Theorising from case studies: Towards a pluralist future for international business research. Journal of International Business Studies, 42(5): 740-762.

Welter, F., Baker, T., Audretsch, D. B., \& Gartner, W. B. 2016. Everyday entrepreneurship: A call for entrepreneurship research to embrace entrepreneurial diversity. Entrepreneurship: Theory and Practice. doi:10.1111/etap.12258.
Yin, R. 2009. Case study research, 4th edn. Thousand Oaks, CA: Sage.

Zhou, L., Wu, W-p, \& Luo, X. 2007. Internationalization and the performance of born-global SMEs: The mediating role of social networks. Journal of International Business Studies, 38(4): 673-690.

Zuckerman, E. W. 1999. The categorical imperative: Securities analysts and the illegitimacy discount. American Journal of Sociology, 104(5): 398-1438.

\section{ABOUT THE AUTHORS}

A Rebecca Reuber (PhD, Queen's University, Canada) is Professor of Strategic Management at the Rotman School of Management at the University of Toronto (Canada). Her research interests include international entrepreneurship and the creation of entrepreneurial ventures, with a particular focus on firms based on digital technologies.

Pavlos Dimitratos (PhD, Manchester Business School, UK) is Professor of International Business at the Adam Smith Business School of the University of Glasgow (UK). His main research interests include small and medium sized enterprise internationalization, multinational enterprise subsidiary activities, and international entrepreneurship. He was born in Athens, Greece, and lives in Glasgow, Scotland, UK.

Olli Kuivalainen, D.Sc. (Econ.) is Professor of International Business and Management at the Alliance Manchester Business School, University of Manchester (UK) and Professor of International Marketing and Entrepreneurship at the School of Business and Management of the Lappeenranta University of Technology (Finland). His main research interests include internationalization of SMEs and international entrepreneurship, and marketing and technology management. 